\section{TWO ELIZABETHAN PURITAN DIARIES}

By M. M. Knappen, $\$ 2.00$

Two hitherto unpublished diaries of Elizabethan Puritan divinesRichard Rogers and Samuel Ward -carefully edited and prefaced with an introductory study dealing with the chief traits of Puritan character in relation to the diaries themselves.

\section{BIBLIOGRAPHY OF}

\section{THE CONTINENTAL REFORMATION}

By Roland H. Bainton, $\$ 1.00$

An indispensable book in this field, particularly for the reader who would rely primarily on English sources.

\section{AMERICAN CONTACTS WITH THE EASTERN CHURCHES 1820-1870}

By P. E. Shaw, $\$ 2.00$

A history of the Greek Mission of the Protestant Episcopal Church, the Episcopal Mission to Constantinople, the work of the A. B. C. F. M. in Turkey and Greece and a history of the indigenous Greek Evangelical Church by an author well-qualified to write on the subject. Most timely in view of the present interest in ecumenical Christianity.

\section{EPISCOPAL}

\section{APPOINTMENTS \\ IN THE REIGN \\ OF EDWARD II}

By W. E. L. Smith, $\$ 1.50$

An exhaustive study based almost entirely upon original material, and filling a need which has not been met hitherto by any other work.

\section{CONGREGATIONALISM IN THE DUTCH NETHERLANDS}

\section{By Raymond P. Stearns, $\$ 2.00$}

The author presents hitherto unpublished documents relating to the English Congregationalists in Holland. New light on the history of Congregationalism.

\section{THE REFORMATION REFUGEES AS AN ECONOMIC FORCE}

By Frederick A. Norwood, $\$ 2.00$

The author examines in great detail the various Protestant refugee communities in England, Germany, Switzerland and the Netherlands. He concludes his study with a critical appraisal of what and how the refugees contributed to the spread of capitalism and the capitalistic spirit.

These prices are only on direct orders from

THE AMERICAN SOCIETY OF CHURCH HISTORY

92 Sherman Street, Hartford 5, Conn. 